\title{
Traditions and Rituals of the Naqsyabandiyah Khalidiyah Babussalam Order (TNKB Practitioners) In the Malay Community Babussalam-Langkat North Sumatra
}

\author{
Multajimah $^{1}$, Ris'an Rusli², Muzakkir ${ }^{3}$, Datuk Imam Marzuki ${ }^{4}$ \\ ${ }^{1}$ STAIS Tebingtinggi Deli Sumut, Universitas Islam Negeri Sumatera Utara, STAIN Mandailing Natal, Indonesia \\ ${ }^{2}$ Universitas Islam Negeri Raden Fatah Palembang, Indonesia \\ ${ }^{3}$ Universitas Islam Negeri Sumatra Utara, Indonesia \\ ${ }^{4}$ STAIN Mandailing Natal, Medan, Indonesia \\ azimah84.haaz@yahoo.com,risanrusligb@radenfatah.ac.id,muzakkirsyahrul@yahoo.com, \\ imammarzuki.1984@gmail.com
}

\section{Abstract}

This research describes the first, the position of Tradition as the culture of the Naqsyabandiyah Khalidiyah Babussalam Tarekat which was cultured in the Malay community (Pengamal TNKB) Langkat has been preserved to this day and has become unique local peculiarities withHaul tradition. This research uses the historical method, it is based on the attempt to describe past and present events with the aspects of a phenomenological approach and a qualitative approach, showing more observation results, current interviews. This research also uses library-research. Third, a shift in the berahoi tradition, that many people have careers in government offices, and there is no land for farming, the Haul tradition which is no longer a media for murshid association and Tuan Guru Babussalam's prominent leadership dualism, since the military aggression in 1947 by the Dutch. In line with the findings of the three facts above, researchers used the theory of Evolutionism as proposed by EB Tylor and LH Morgan. When culture develops, there will be a meeting with other cultures, so that the mutual influence between major cultures affects local culture (peripheral culture) which is called Great Tradition and Litel Tradition. The process of change did not occur suddenly, but with an evolutive mechanism, slowly but surely. So that the mutual influence between major cultures influences local culture (peripheral culture) which is called Great Tradition and Litel Tradition. The process of change did not occur suddenly, but with an evolutive mechanism, slowly but surely. So that the mutual influence between major cultures influences local culture (peripheral culture) which is called Great Tradition and Litel Tradition. The process of change did not occur suddenly, but with an evolutive mechanism, slowly but surely.
Keywords

position; shift, ritual; naqsyabandiyah khalidiyah order, tradition

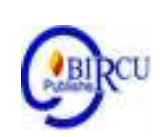

\section{Introduction}

The arrival of Islam in Sumatra, where tarekat followers played an important role in the spread of Islam. By using the material of preaching that is conveyed contains elements of Sufism. It cannot be denied that initially Islam in Indonesia was known as Islam Sufism. Recorded in the history of the Langkat region of North Sumatra when it was controlled by the Azizi Sultanate which was dominated by the Malay community, it was considered quite strong in holding ancestral teachings. 
In Langkat, North Sumatra, there was also a great scholar, this ulama was quite well known in most of the land areas in East Sumatra Malay. He is very intelligent and creative, so he has written many great works in the field of Sufism. The book that he wrote in Malay was able to have a pretty great impact on the progress of Sufism in Indonesia. At that time, the mixture of two very different cultures, namely the culture of the Nusantara (Malay) people. with the culture of generally Middle Eastern alumni can bring new clothes to life. The results of this culture do not lean towards the teachings of the local population. But the advantages that we can see from the emergence of this new culture are in the success of the preachers in spreading the values of Islamic aqodah and applying them in the lives of the people there.

By the twenty-first century it became clear that the Naqsabandiyah Besilam order had become a dynamic part of the religious life of the local Islamic community. Even more than that, is at the forefront of the expansion of Islam, not only in rural areas, but also in modern societies, both elite and intellectual. This prolific view reflects part of the history and complex developments concerning the Naqsabandiyah Besilam Langkat since the eighteenth century. There is a major continuity of experience in the tarekat, it provides an important background for the development of religion. The rituals of popular piety among educated and uneducated Muslims, both from the countryside, cannot be ignored.

The intellectual appeal of his ritual practice remains strong, and the sense of social cohesion provided by the Naqsabandiyah Besilam Langkat organization is important. Likewise, community participation in the form of a tradition that is regularly accompanied by the ritual practice of the tarekat. This is interestingly revealed by the participation of the community in the tarekat, which was originally based in the countryside, and later the Naqsabandiyah Besilam Langkat institution was formed, which was formed by followers of a new branch in the city.

\section{Research Methods}

This research uses qualitative analysis principles. In qualitative research, it requires a depth of analysis, objectivity, systemic, so that accuracy in interpretation is obtained, because the essence of this phenomenon for adherents of qualitative research is totality. Judging from the research objectives are divided into descriptive research, explorative research, development research research or operation research, and verification research. Malinowski's theory of functionalism is suitable for analyzing this research. As explained above, Malinowski's theory of functionalism is able to reveal a community function related to the teachings of the tarekat. Apart from the above theory, the writer also uses the Theory of Evolutionism to clarify the meaning of this dissertation writing. The point of view of Evolutionism is as expressed by EB Tylor and LH Morgan that, "evolutionism is a process by which human society and culture on this earth develops from the lowest level to the highest level, driven from within the individual to evolve".

\section{Discussion}

Tradition is something that is passed down from the heritage of the ancestors to the next generation in a relay descends performed by the indigenous communities that have become deeply entrenched the culture in life. Customs and traditions include the creation and work of human beings who have become convictions in regulating the social order of life. (Pane et al, 2020). 
Religion has a function to foster brotherhood especially among internal religious communities. But like the two sides of the religious coin, it has a dual role to play between integrative functions and disintegrative functions in social reality, depending on the context of internal or external relations of religious communities. (Muda in Saburi, 2020)

Religion is one of the emerging issues in the modern era and forms the backbone of most literary works. Religion as a theme is seen to influence the operation of those who believe in it. Religion is predominated in Dubliners. It forms the functional framework that predetermines ones actions and behavior. James Joyce's Dubliner is a vivid collection that depicts conflicts that exist between the modern era and the early times of the 20th century in terms of beliefs and cultural practices (Parrinder in Eskandari, 2020).

The Naqshbandiah Order has several rituals for worship, spiritual techniques and special rituals. It can be said that the Nasabandiyah Order consists of: worship, techniques, and rituals, and the basic meaning of the term "path" of the Tariqoh. Adaptation occurs because circumstances do change, different teachers have emphasized different aspects of the same principle, and reformers have abolished certain thought patterns or practices and introduced something else. In reading the discussion about the following basic thoughts and rituals, it should always be remembered that in daily practice there are many variations. following traditions:

\section{Teachings of Sheikh Abdul Wahab Rokan a. Humming Tradition}

The content in the chanting of Babussalam is expressions of praising the greatness of God, besides that what is the most important part is also remembering the great figures in Babussalam, namely Syekh Abdul Wahab Alkholidi Naqsyabandi, he has spread the teachings of Islam and the Tharikat Al Naqsyabandi.

Senandung Babussalam is the only chant that only exists in Babusalam village, Langkat Regency. The specialty of this hum is that it must be performed in a distinctive and high tone, it must be performed alone. The beauty of the hum is also determined by the humming in the tone and rhythm. Because of this, not everyone can sing this chant, because the twists and turns have to be adjusted to the songs of the Malay people. The distinctive feature of the Malay Babussalam community is known as the chanting Babussalam. Since the entry of TNB in Babussalam, as a form of one of the teachings conveyed by Syekh Abdul Wahan Rokkan to TNB followers, According to the informant, Ustadz Akhyar Murni, that:

"What is meant by hum is a song in the form of a verse that is read or sung every half hour before the call to prayer every day, after munajat or praising the greatness of Allah SWT and at the time of Haul, maulid and marhaban then chants are read. The hum that is read every day on the tower of the madrasa waiting for the prayer time to arrive which is carried out alternately by 3 (three) to 4 (four) people and the second munajat is read out before the dhikr ritual in suluk begins."

This Senandung originates from Bessilam in the Padang Tualng sub-district, Langkat Regency, and is named Senandung Babussalen. A. Fuad Said is a figure or scholar who wrote history about Babussalem, since this time the local community has become familiar with the humming of Babussalem. After him, one of the tarekat congregations followed in his footsteps to compose poetry, a chant he made to commemorate the ulama leaders in Babussalem, namely Sheikh Abdul Wahab Rokan. Then this hum was sung or sung by one of the Babussalem community, Ustadz H. Akhyar Murni. 
And according to Ustadz Akhyar Murni:

"Senandung Babussalam has a close relationship with the people of Babussalam because until now it is still used or chanted so that it is always known by everyone. In addition, the chanting of Babussalam is one of the cultures so that the community is not influenced by music from outside which starts to influence the people's lifestyle, especially in Babussalam so that the Babussalam chant continues until now".

So of course the tradition that is continuously carried out in culture is not easy to shift, because it is continuously carried out by both Al Ustadz Akhyar Murniy as the singer of this song and also the local community who are given the confidence to recite it at certain times. In accordance with the interview with Ustadz Akhyar:

"Senandung has not changed at all until now it has been carried out, the lyrics have not changed because the contents tell the history of Tuan Guru Babussalam Syekh Abdul Wahab Rokkan from his birth, family history and his descendants, his life journey, his journey as a student to becoming Tuan Guru. Babussalam in developing tharikoh, until the end of his life, from the beginning of the chanting begins to this day it is still chanted and no change occurs in the verse and its implementation.

The observations made by the researchers, to this day that the implementation of the chanting continues to be carried out and in an effort to commemorate the former TNB founder, Syekh Abdul Wahab Rokan, is the poetry of TNB adherents, congregations and followers of the life story and missionary journey of Syekh Abdul Wahab Rokan in developing TNB, until with him died and completed his missionary journey as a teacher and founder of TNB. Poems or poems from every chant of previous scholars, meaning that people who hum and listen to humming think that they only enjoy the lyrics and poetry, do not study the history and practices taught by Sheikh Abdul Wahab Rokan, so that they think that these poems are only touches and entertainment .

\section{b. Munajat Traditions (Istiqfar, Salawat, and Tarahim)}

Implementation of munajat (Istiqfar, Salawat, and Tarahim) in the Orderdone to ask Allah for supplication and forgiveness, this chant was sung by a teacher or scholar whose religion was undoubtedly. Habits that are often carried out by the people of Babussalem are at the time of the entry of prayer times such as evening prayers, sunset, dawn, as well as sunnah prayers, bilal or mosque guards stay on top of the minarets or near the mosque pulpit to hum praises or prayers' a. Not only in the normal months of Ramadan before the time of Isha, this will still be done. The munajat to be carried out consists of 44 (forty four) stanzas, which also contain praises to Allah, prayers for the afterlife and asking for blessings on Naqsyabandiah Shaykhs as well as great and pious Guardians of Allah.

"Munajat poetry was created by the first master teacher, Sheikh Abdul Wahab Rokan Khalidy Naqsyabandy during his lifetime. This reading of munajat began when the village of Babussalam was first established, namely on the 15th of Syawal $1300 \mathrm{H}$. The term munajat refers to 2 (two) meanings, namely munajat as a chant that is read bilal every day on the madrasa tower waiting for prayer times to arrive which are carried out alternately by 3 (three) to 4 (four) people and the second munajat is recited before the dhikr ritual in suluk begins.

Due to the wider spread of the tarekat and being accepted by the outside community, this reading of munajat is also carried out in other areas, which still adhere to or believe in tarekat ideology. Likewise in Babussalem, in other places, the reading of the munajat is echoed while waiting for the times for the dawn prayer, agrib, isya ', and Friday. The reading of this tarekat is considered important for adherents of the Naqsabandiyyah tarekat, because they 
think that this munajat is a form of a student's obedience to his teacher and also respects a culture that has existed since hundreds of years ago. This munajat is called rahbithah and wasilah. As for the technical implementation of the Munajat tradition during an interview with Mr. Akhyar Murni, as follows:

"In its implementation, munajat always begins with beating the nakus for ten to fifteen minutes by hitting the inside of the nakus and ends with beating on the outside of the nightstand as much as the number of rakatsalat to be carried out. Furthermore, the reading of the munajat will be carried out in the highest tower in the Babussalam madrasah until the time for the call to prayer for prayers will arrive. Munajat reading is carried out with great care and discipline, this is when he recites Munajat. Therefore, every day Bilaldimadrasah Babussalam must be present one and a half hour before entering the time to prayer. After the reading of Munajat is finished, it is continued with the recitation of taharim and salawat. "

The purpose of the munajat is to warn the public to stop all their activities such as dhikr or trade to get ready to perform congregational prayers at the madrasa. Usually 1 (one) hour before dawn, the community begins to be seen carrying out activities to prepare for congregational prayer, starting from getting ready for all worship needs such as a covering (sarong / veil) for tawajuh, prayer beads and for those who have had the pilgrimage or reached the caliphate wearing white clothes.

Munajat is a way of giving birth to love, because true love is only in Allah SWT, which cannot be penetrated by human reason. As Carrel's statement written by Ali Shari ati, reads; prayer and munajat are a reflection of love and a reflection of spiritual desire for humans. Thus, the most perfect human being is the one who most needs and thirsts for being.

Meditating to Allah and there is also dhikr in which it is a dialogue or conversation between the servant and his God. Dhikr which contains the expression of a servant to his god is called munajat, but usually munajat can be done by someone who has reached a separate state. The moral messages and lessons contained in Unajat can touch the hearts of the adherents. Examples of Sya'r Munajat, namely:

O Allah yaahadii

Gift us thought and mind

Day and night grew so

Thanks to Mr. Shaykh Abdullah Damalu in the country of Hindi ...

Thanks to 'Ali Romatni Karuniai our Laduni knowledge

Hopefully its almost god

ghani To us fani servants ...

Thanks to Yusuf Hamdani

Also gift $O$ Allah servant-

$M U$ will this knowledge and wisdom laduni

Musyahadah

Muqarabah of God

Robbani...

The example of these verses has explained to us that education is very important and necessary because it is one of the conditions for obtaining the level of musyahadah. The message of the moran contained in the above verse is intended for Allah to give us good thoughts and intellect. 
With Munajat, the Naqsyabandiah Order can spread teachings to Islam and morality. In history it has been proven that Islam began to develop and be accepted by the community when Islam was able to mix and adapt to the local environment. It has the same rights as the Naqsyabandiah Order known in the Langkat Malay area. The local community really exalts and likes munajat because apart from being the local wisdom that is there, the contents of the content contained in munajat are also very inspiring and motivating for every listener. One example of Munajat's verse such as:

Thanks to Muhammad aulia Allah, the world and the hereafter are hated. Hopefully in Allah's substance, Give us such

Add by You we are Thanks to Abdul Khaliq PanjuduaniMore than jidini veins felt Ma'rifat imaninurani ...

\section{Thanks to Yusuf Hamdani}

Give also O Allah, Your servant Will

knowledge of wisdom and laduni

Musyahadah Muqarabah Lord Robbani ...

The moral message contained in the munajat above is that for every Muslim it is recommended to study laduni and wisdom based on the sciences of sharia, ma'rifat, tarekat and also nature, this is in order to fight the lusts that affect themselves. The syiir also contains a message to demand the knowledge of tauhid, the science of tawhid which later explains the existence of God, the master is indeed true and can also keep us away and prevent us from sin due to shirk and hypocrisy.

If viewed as sharia, surrendering oneself to oneself means giving up and surrendering oneself to the teacher to be guided and guided to the correct teachings. However, from the point of view of tauhit, submission (bai'ah) is a form of surrendering to Allah and also promising Him to always obey and obey all his commands and stay away from all his prohibitions. the form of carrying out the bai'ah ritual should be repentance nasuha (sincere repentance) who previously had to perform repentant baths. Syair Munajat below explains:

Thanks to Said Kulal the most noble guardian

Give us all light, $O$ Allah

Until lost power and effort

To see Allah's supreme substance.

Thanks to Muhammad Babassamaasi

Close to us' Ars and chairs

Until the difference between fire and iron

Until we know we are skin and filling ... 


\section{c. HAUL Tradition (The First Day of Birth of TGB)}

"In language the word haul comes from Arabic, which means a year, commemorating haul means commemorating one year".A form of celebration or commemorating the death of someone who is considered great every year. In general, this haul is carried out on the date of the person's death. Today, haul is a promising tradition among Muslims. Haul has become a hereditary tradition that can connect from generation to generation. Inside the haul, there is a nuance of the charisma of the exalted figure, so the greater the charisma, the greater the atmosphere of the haul at that time.

Commemoration of Haul Tuan Guru Babussalam who still survives, this tradition is a part of the community that cannot be separated or even forgotten. With a tradition like this, every time they want to carry out any celebration, the people there always first do ziaroh and pray at the tomb of Tuan Guru Babussalam. This belief causes people to have religious nuances.

This spiritual tradition is also found at the moment of "facing" Tuan Guru as is the prevailing tradition in TNB that the important moment besides being raised is "facing" Tuan Guru. Because, facing Tuan Guru is an important part of the effort to convey one's desire and wishes. The effort to "face" Tuan Guru is of course related to the conviction among pilgrims that Tuan Guru is a pious and privileged person.

So of course "facing" Tuan Guru to convey directly all wishes is an important part and has always been the wish of every pilgrim who comes from various regions. At the moment of haul "facing" Tuan Guru is very difficult compared to normal days because of the large number of pilgrims who come, so at this moment it requires pilgrims who want to meet Tuan Guru have to queue, which sometimes takes a long time.

According to Mrs. Nurainun P., one of the pilgrims who came from Labura;

"Facing Tuan Guru is very important, because the moment of haul is very much awaited by pilgrims who come to Besilam, to convey their wishes and intentions to go to Tuan Guru, like I want to ask for water and prayers for the recovery of my second child who is constantly sick, It is an extraordinary feeling and the experience that is eagerly awaited if you can face the Master Teacher is a worthwhile struggle on a long journey that is taken to be a joy to be grateful for".

From the observations of researchers, the implementation of the Haul tradition is a commemoration that is carried out every year, namely on the 21 st (twenty one) of Jumadil Awal in Babussalam Langkat, at that time the researchers mingled with the local TNB community with congregations who were present to commemorate Haul Tuan Guru Babussalam from various in North Sumatra and from outside Sumatra as well as from abroad, Malaysia, Brunei Darussalam, Singapore and Thailand. Tens of thousands of people attended the event, making it look like a sea of people, consisting of: Zurriats, Khalifahs, Students, Jamaahs, TNB sympathizers and government officials at the regional / regency levels, even at the provincial and national levels.

It can be seen how enthusiastic the visitors who came from a few days before the implementation of this Haul, for the 3 days 3 nights event from 19-21 Jumadil Awal by Mursyid / Nazir Babussalam slaughtered dozens of oxen, buffalo and tens of tons of rice for a banquet with visitors. The materials obtained from the assistance of students, caliphs, sympathizers and local governments. It can be seen how enthusiastic the visitors and the Haul commemoration were intended for Ukhuwah Islamiyyah to strengthen the friendship among TNB adherents who are scattered in various regions. From several interviews and observations made in the field, that this event was not intended to cult the figure of Tuan Guru Babussalam.

Because in the Naqsyabandiah adab a student should visit his teacher once a week, if it can't be done then once a month, if he can't afford it, then a pilgrimage is carried out in the 
sense of meeting a teacher who is still there or visiting his grave, then at least one once a year, at this Haul moment, a great pilgrimage moment complete with various rituals and traditions that are carried out.

This is how students love their teacher, according to them that it is impossible to love their Lord if they do not love their Messenger and perhaps love their Rasul if they don't love their teacher. As for the Haul TNB moment, there are events such as: Praying in congregation at any time, reciting (Tawajjuh) in congregation, memorizing the Qur'an, Mawlid Nabi, Qasidah, Ratib Saman, also reading and appointing new caliphs who receive diplomas for redeveloping the Naqsyabandiah Tarekat existing in their respective areas as well as reading the history of Sheikh Abdul Wahab Rokan in front of the Naqsyabandiah congregations and government officials also participating.

Several times the researcher met with the figure of the deputy governor of North Sumatra, Mr. Ijekh, who followed the tradition of Ratib Saman at Mr Guru Syekh Abdul Wahab Rokkan's meal and ended with a feast (eating together) at which time the researcher could sit together with the female zurriat in the room of Tuan Guru's residence and join the journalists from Metro TV and various media journalists who were women who faced each other and closed by shaking hands and talking to each other privately were the researchers witnessed.

\section{d. Water Yasin Tradition (Air Recitation)}

The TNB ritual is also found in this haul moment, namely "yasin water". "Air Yasin" or also often referred to as "dhikr water" is water that has been recited by the TNB pilgrims thousands of times, which is usually done every Friday night in the area of Tuan Guru's grave. "Yasin water" is believed to be used as medicine by TNB congregations and pilgrims who come to avoid all the bad things that will happen to themselves or their families. Through an interview with Mr. Akhyar Murni, he explained, namely".

"The procession makes" Yasin water "as this medicine by drinking it or rubbing it on the whole body that is experiencing pain so that all forms of disease can be removed and the body will be healed. There is also mixed with other water for bathing, depending on the pilgrim's celebration. Of course this procession must first follow the traditions that apply to TNB such as reading prayers, zikir, prayers and others ".

Yasin water is water that is used as medicine for the public's belief that it is a holy water for pilgrims to fulfill the desire. Likewise, facing Tuan Guru in order to get yasin water as wasilah, for the sake of healing the congregation who has a desire for an illness. Many congregations, sympathizers and TNB adherents who come to visit the nickname location, it is very useless if you don't come home with gifts in the form of Yasin water that has been recited a prayer.

Quoting what Dr. Emoto said that water is able to hear messages given according to what they want to say. Therefore, water if we pray solemnly to Allah will be processed by the body according to the request because the message given to drinking water will enter the brain and blood vessels. The body is a constitution that is built through water, water becomes part of the characteristics of humans, it is said because the nature of human behavior is often the same as water. If seen biologically, physically or psychologically this is very possible. With Allah's permission the message will be entered and will be granted.

But once again Mr. Shaykh always reminds us that healing comes from God, humans only try and the prayers we say in prayer, dhikr as a medium for pleas to facilitate healing comes and all wishes are fulfilled. for free. There is a fee to be paid in exchange for yasin water. According to the current master teacher, there are people who take the time to prepare this yasin water. Either through dhikr and prayer as well as time-consuming yasin recitation. This 
award is given for the efforts of these pious people in helping the congregation to get yasin water. On the other hand, there is sincerity in giving and there is gratitude for the TNB party to receive the gift. Because there is a belief in Yasin water as a medicine for the desired urges.

\section{e. Khatam Tawajjuh tradition}

In the Naqyabandiyah Babbussalam Langkat tradition there is a tawajjuh tradition. The Tawajjuh tradition means face-to-face, in the Naqsyabandiyyah tarekat, tawajjuh is a meeting of a student with his teacher whose heart seems to feel that the teacher has watered his heart with blessings. Then Tuan Guru finally brought the heart to meet the prophet Muhammad. This is a meeting of the student to the teacher who must imagine the Master Teacher who is in sight. As it is found in various orders, that Tuan Guru and Murshid greatly influence the spiritual development process for their students. This is done in various ways according to the character of each student. such as teaching either directly or through a process called tawajjuh, which means "face to face" between the murshid and his student. In accordance with the interview expression delivered directly by Mr. Yaqhdum, namely:

"The nickname starts after performing the tawajuh khatam after the Asr prayer,Form a circle and sit in a bargaining position. A teacher will say hello, greeting here is meant by opening before dhikr. After a teacher recites istighfar once, then a student recites istighfar 25 times, sholawat 25 times and reads AlIkhlas, Al-Falaq, An-Nas once. After reading istighfar, prayers, and letters. A student recites Anta Maqsudi Wa Ridoka Matluubi before going to dhikr. Then a student dhikr as much as he wants, where in this dzikir a student dzikir to remove the qualities that are in Lathifatul Qolbi, which is two fingers below the left milk. A teacher will approach the Ikhwan (students) in turn, where a teacher will transfer his knowledge in a way. The teacher will put his sirah on the student and his knees stick together, when the teacher transfers his knowledge, an ikhwan prays or agrees to it in his heart. The position of a student opens his hands like a person praying. After a teacher is finished, a teacher will read a prayer. Which is where the prayer is known only to a teacher. Reading the tawasul of the masyaikhs".

Tawajjuh namely a meeting of a student with Tuan Guru, this activity is carried out by a student who opens his heart to Tuan Guru by expecting blessings from the Sanguru. Which later Tuan Guru brought the hearts of his students to the Prophet Muhammad SAW. This takes place when the direct meeting between the murshid and his student begins with the bai'at (appointment) process, which is the initial stage of entering tawajjuh in the Naqsyabandiah Babussalam / Besilam thariqat. The implementation of this Tawajjuh can take place even though the murshid or master teacher does not attend, because later the teacher will carry out rabithah, which is a bond that can connect the hearts of everyone who performs this rabiahi against the resistance of the murshid.

Naqsyabandiyah Orderhave a daily wazifa which is always done regularly, be it done individually or in congregation. Tawajjuh ta 'aruf is carried out with the aim of establishing friendly or fraternal relations between members. while Tawajjuh akbar is carried out at certain times and the association is also determined. In line with the interview by Mr. Yaqdhum, namely:

"The rules for sitting at the time of Berkhatam Tawajjuh, concerning manners and order, are recommended to young and old alike. Let the Khaleefahs sit on the right hand of Mr. Shaykh (Guru), three people. And if there are more than three caliphs, then sit on the left of the Shaykh. It is hoped that more people sitting on the Shaykh's right side than on the left. And let us sit in an orderly manner, as arranged by the previous Masyaikhs, namely the older one sits on the right of the Shaykh, then the 
younger one sits on the left of the Master Shaykh. Thus the rules are made successively, and when the Shaykh Arises to Preserve the one on the right. So it is not permissible to rise up the Old Caliph, but the way Mr. Shaykh used to pass by someone from the Jama'ah. Only then can the Caliph rise up to Menawajjingan on the left. So it is the Caliph who is the Old One who may offer to the left, because he is forgiven.

Shaykhs or murshids have a very important role in the spiritual progress of the students. Concentration, mindfulness or "turning one's face on something." Tawajjuh can refer to the spiritual concentration that occurs between the murshid and the disciple. At a higher level of meaning, tawajjuh means God's attention to something that might cause that something to come into existence. The tawajjuh tradition can be a way or process of spiritual activities which will later lead the congregation to always remember Allah by means of a sermon against a teacher. Later the teacher teaches some dhikr in order to get closer to Allah. A teacher teaches dhikr to his students from generation to generation, so that the knowledge he has is not lost and can be taught again to students who will come later.

\section{Conclusion}

Based on the explanation of the findings above, The researcher conveyed the novelty, Hereustik or novelti of this work, the writer included several studies to compare with the researcher's findings. Based on the descriptions above, the authors menarik the conclusion that, the present traditions and rituals of the Naqsabandiyah Babussalam Langkat are the original teachings of Sheikh Abdul Wahab Rokan with his blessing, namely: Humming Tradition, Munajat Tradition (Istiqfar, Salawat, and Tarahim), HAUL Tradition, Air Yasin Tradition (Air Recitation), Khatam Tawajjuh Tradition. As for Rituals; The teachings approved by Sheikh Abdul Wahab Rokan include: Ritual of Recitation and Prayer, Congregational Prayer Ritual, Suluk / Khalwat Ritual, Saman Ritual, Yasin 41 Ritual, Bai'at Ritual (Oath or Statement of Loyalty), Tahlilan Ritual, and Alms Ritual.

As for Traditions and rituals of the local Malay community in Babussalam Village, namely: Berahoi Tradition, Barzanji Tradition, Barzanji Tradition, Akikah Tradition, Sacrifice Tradition, Yasinan Tradition, Mutual Cooperation Tradition, and Circumcision Ritual. In line with the above findings the researcher usesRationality theory of Max Weber's thinking. This is because Max Weber's rationality theory is relevant to the problems that will be studied by researchers, because this study investigates the actions of tarekat followers in the modernization process. 


\section{References}

Alwi Shihab, Islam Sufistik, Islam Pertama dan Pengaruhnya Hingga Kini di Indonesia

Ahmad Fuad Said, (1983), Syeikh Abdul Wahab Rokan: Tuan Guru Babussalam (Medan: Pustaka Babussalam)

Dede Mulyono, (2002), Metodologi Penelitian Kualitatif, (Bandung: Remaja Rosda Karya)

Denys Lombard, (1990), "Tarekat et Entreprise à Sumatra: L'exemple de Syekh Abdul Wahab Rokan (c.1830-1926)", dalam Marc Gaborieau, e.al., ed., Naqshbandis: Cheminements et Situation Actuelle d'un Ordre Mystique Musulman (Paris: Institut Français d'études Anatoliennes d'Istanbul

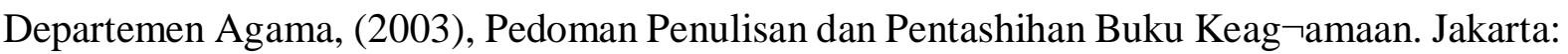
Penerbit Proyek Pengkajian dan Pengembangan Lektur Pendidikan Agama

Eskandari, S. (2020). Social and Religion Paralysis in James Joyce's Short Story The Sisters: A Cultural Reading. Budapest International Research and Critics Institute-Journal (BIRCI-Journal). P. 311-320

J. Fachruddin Daulay, (1994), et.al. Sejarah Pemerintahan Kabupaten Daerah Tingkat II Langkat. Langkat: Kerjasama Pemda Tingkat II Langkat dan Jurusan Sejarah Fakultas Sastra USU

J. Suyuti Pulungan, (2014), Pemimpin dan Kepemimpinan dalam Persfektif Islam, (Yogyakarta: Idea Press)

Jacobus Ranjabar, (2006), Sistem Sosial Budaya Indonesia, (Bogor: Ghalia Indonesia).

Jhon O. Voll dalam Martin Van Bruinessen dan Julia Day Howell (ed), (2008), Urban Sufism (Jakarta: Rajawali Pers)

Pane, A., et al. (2020). The Performance of Mangupa Tradition in Angkola Custom, Medan, Indonesia. Budapest International Research and Critics Institute-Journal (BIRCIJournal). P. 1747-1757

Piotr Sztompka, (2011), Sosiologi Perubahan Sosial, Cetakan ke-06, (Jakarta: Prenada)

Proyek Pembinaan Perguruan Tinggi Agama Islam Sumatera Utara, (1981/ 1982), Pengantar Ilmu Tasawuf.

Purwanto S.U, (2007), Sosiologi Untuk Pemula, (Yogyakarta: Media Wacana)

Pustaka Babussalam, (1984), Kafiat Zikir Naqsyabandiah Besilam-Babussalam.

Saburi, et al. (2020). Contribution of NEO Modernism Thoughts on Islamic Thoughts in Indonesia. Budapest International Research and Critics Institute-Journal (BIRCIJournal). P. 1443-1452. 